\title{
Przedsiębiorczość w edukacji przedszkolnej i szkole podstawowej w warunkach zmian podstawy programowej
}

DOI: 10.47050/65591760.122-141

Wioletta Kilar, Tomasz Rachwał

Powszechnie przyjmuje się, że celowe jest włączenie treści z zakresu przedsiębiorczości w podstawy programowe i programy nauczania niemal wszystkich przedmiotów szkolnych od najmłodszych etapów edukacji. Podstawa programowa w Polsce, wprowadzana sukcesywnie w szkołach podstawowych od 2017 r., stara się nawiązywać do tej idei. Celem niniejszego opracowania jest więc przedstawienie wyników analiz nowej podstawy programowej wychowania przedszkolnego i kształcenia ogólnego w szkole podstawowej pod kątem treści związanych z przedsiębiorczością oraz próba odpowiedzi na pytanie, w jakiej mierze zapisy nowej podstawy programowej sprzyjają kształtowaniu postaw przedsiębiorczych dzieci i młodzieży.

\section{Słowa kluczowe:}

edukacja dzieci i młodzieży

edukacja w zakresie przedsiębiorczości

podstawa programowa

postawa przedsiębiorcza

rozwój dziecka 


\section{Entrepreneurship in preschool and primary education and the core curriculum changes}

DOI: 10.47050/65591760.122-141

Wioletta Kilar, Tomasz Rachwał

It is generally accepted that it is purposeful to include entrepreneurial goals and content in the curricula of all school subjects from the youngest stages of education. The new core curriculum in Poland, introduced successively at primary schools since 2017, tries to refer to this idea. The aim of the chapter is therefore to present the results of analyses of the new core curriculum of preschool education and general education in primary school in terms of entrepreneurshiprelated content. It answers the question to what extent the provisions of the new core curriculum favour the shaping of entrepreneurial attitudes of children and youth.

\section{Keywords:}

education of children and youth

entrepreneurship education

core curriculum

entrepreneurial attitude

child development 


\section{Wprowadzenie}

Przyjmuje się powszechnie, że przedsiębiorczość nie jest wrodzoną cechą osobowości człowieka, ale postawą, którą można kształtować i rozwijać w toku wychowania i edukacji szkolnej od najmłodszych lat. Poznawanie i stopniowe rozumienie otaczającego świata następuje u dziecka od pierwszych dni życia, gdyż każdego dnia nabywa ono nowych umiejętności i pogłębia swoją wiedzę w zakresie funkcjonowania otaczającego je świata, co odbywa się zarówno formalnie, w przedszkolu czy później w szkole, jak i nieformalnie, w codziennym życiu. W tej sytuacji również kształtowanie postaw przedsiębiorczych następuje stopniowo i odbywa się przez obserwację dorosłych, szczególnie rodziców i pozostałych członków rodziny, oraz przez uczestnictwo w zajęciach przedszkolnych i szkolnych. Szczególną rolę w początkowych latach życia odgrywa kształtowanie postaw twórczych, które należy zaliczyć do podstawowych elementów postawy przedsiębiorczej. Kluczowe jest tutaj wspieranie dziecka w rozpoznawaniu i rozwijaniu własnych uzdolnień oraz zaradności i inicjatywności, a także sztuki uczenia się, która jest fundamentem dalszego zdobywania wiedzy i nowych umiejętności. Jest to bardzo ważny aspekt przedsiębiorczości. Lidia Wollman $(2015,2017)$ podkreśla, że przedsiębiorczy człowiek chce, lubi i potrafi się uczyć, nieustannie rozwija swój potencjał i wciąż dąży do nowych celów, a także wykorzystuje wszelkie zasoby wokół siebie (materialne i ludzkie), by wspomóc swój proces uczenia się i różne strategie poznawcze. Przedsiębiorczość w zakresie uczenia się powinna więc być kształtowana i rozwijana od najmłodszych lat, na co wskazuje wielu autorów (por. między innymi: Oeszlaeger-Kosturek 2017, Rachwał 2005, 2006, Raszka 2017, Wach 2013, 2014, Wollman 2017, Zioło 2012). Umożliwia to przygotowanie młodego człowieka do wyzwań, jakie czekają go w życiu dorosłym, kiedy będzie musiał wziąć odpowiedzialność za swoje życie zawodowe i rodzinne. Tych wyzwań we współczesnym świecie jest wiele, gdyż w dzisiejszej, dynamicznie zmieniającej się rzeczywistości nie można niczego być pewnym, szczególnie w zakresie długoterminowych perspektyw rozwoju kariery zawodowej. Jako nauczyciele musimy mieć świadomość, że nasi uczniowie będą funkcjonować w świecie, którego kształtu nie znamy, pracować w zawodach, które jeszcze nie istnieją, i wykonywać obowiązki zawodowe, o których obecnie nie mamy pojęcia, a które mogą różnić się znacznie od tego, jak wyglądają one dzisiaj. Stąd konieczne jest przygotowanie 
w toku edukacji przedsiębiorczego i kompetentnego człowieka, który będzie w stanie sprostać tym wyzwaniom i adaptować się do zmian otoczenia, osiągając przy tym własne cele życiowe i realizując zamierzenia. Podstawową rolę $w$ tym zakresie odgrywają - oprócz rodziny czy rodziców - przedszkole i szkoła. Dlatego ważne jest ustalenie, w jakim zakresie dokumenty programowe wyznaczają podstawy (cele i treści) kształcenia i umożliwiają rozwijanie postaw przedsiębiorczych czy wręcz wskazują na taką konieczność. Podstawowym celem niniejszego opracowania jest przedstawienie zmian, jakie zaszły $w$ tym zakresie w warunkach reformy programowej systemu oświaty, wdrażanej od 2017 r. w Polsce.

\section{Wprowadzenie do kształtowania postaw przedsiębiorczych w świetle podstawy programowej wychowania przedszkolnego}

Edukacja ekonomiczna dzieci w krajach zachodniej i północnej Europy jest prowadzona z reguły bardzo wcześnie, zwykle już na etapie przedszkola. Choć kształcenie w zakresie przedsiębiorczości w Polsce - $w$ formie oddzielnego przedmiotu szkolnego - rozpoczyna się dopiero od szkoły średniej, co było przedmiotem analizy wielu autorów (por. między innymi Rachwał, Kurek, Boguś 2016), to również w Polsce treści z zakresu przedsiębiorczości są wplecione w podstawę programową wychowania i nauczania najmłodszych dzieci. Nie jest to coś zupełnie nowego związanego z reformą systemu szkolnictwa od 2017 r. Jak wynika z badań M. Tracz (2015), która przeprowadziła analizę kształcenia w zakresie przedsiębiorczości w Polsce na tle krajów Unii Europejskiej, kształcenie w zakresie przedsiębiorczości jest jednym z priorytetów polskiej polityki edukacyjnej. Autorka wcześniej wskazywała również dużą rolę podstaw przedsiębiorczości w kształceniu ogólnym (Tracz 2006).

Porównując poprzednią (z 2012 r.) i nową (z 2017 r.) podstawę programową (Rozporzq̨dzenie MEN... 2012, 2017) w zakresie treści związanych z przedsiębiorczością, nasuwa się kilka głównych wniosków związanych ze zmianami treści podstawy w przedszkolu i szkole podstawowej.

W podstawie programowej wychowania przedszkolnego ogólnie rozszerzono problematykę przedsiębiorczości na tym najniższym szczeblu kształcenia. Wymagania szczegółowe w tym zakresie wpisują 
się w społeczny obszar rozwoju dziecka. W poprzedniej podstawie programowej sformułowane było tylko jedno ogólne wymaganie szczegółowe, w nowej zaś występują cztery wymagania w zakresie umiejętności społecznych, dotyczących przede wszystkim komunikacji, gospodarstwa domowego oraz życia zawodowego najbliższych (Tab. 1). Tym samym kształcenie w obszarze przedsiębiorczości rozpoczyna się od najmłodszych lat szkolnych przez poznawanie tych zagadnień w najbliższym otoczeniu dziecka.

Odnosi się to w pierwszej kolejności do kształtowania poczucia własnej wartości, na której buduje się umiejętności komunikacji i relacji z innymi ludźmi, niezbędne w życiu prywatnym i w aktywności zawodowej, szczególnie biznesowej, każdego człowieka. Na tym etapie pojawia się także element edukacji finansowej (rozumienie roli pieniądza w życiu rodziny, rozpoznawanie monet i banknotów) oraz związanej z pracą zawodową, co stanowi podbudowę późniejszych treści kształcenia dotyczącego funkcjonowania rynku pracy (na przykładzie wybranych zawodów). Są to ważne treści kształcenia na tym etapie, na co zwracał uwagę T. Kopczyński (2017), wskazując je jako jeden z brakujących elementów kształtowania przedsiębiorczości w przestrzeni edukacyjnej. Choć problematyka ta była realizowana na zajęciach w przedszkolu, to na uwagę zasługuje fakt, że została obecnie wyraźnie zapisana w podstawie programowej i staje się obowiązkowa w kształceniu już na tym etapie, gdyż we wcześniejszej podstawie programowej treści z tego zakresu były zapisane w ramach edukacji wczesnoszkolnej.

Na rolę edukacji finansowej dzieci, mając świadomość znaczenia tej sfery życia w pomyślnym rozwoju i przyszłości kolejnych pokoleń, zwracało uwagę wielu autorów, między innymi R. Raszka (2017). Wskazuje ona, powołując się także na innych autorów, że edukacja finansowa staje się niezbędną, nawet pilną potrzebą w obecnych czasach, a wychowanie dzieci w tym zakresie jest koniecznością. Wynika to z faktu, że rozumienie wartości pieniądza i radzenie sobie z obliczeniami pieniężnymi należą do podstawowych umiejętności życiowych (Raszka 2017). 
Tabela 1. Zakładane efekty kształcenia związane z przedsiębiorczością zapisane w treściach nauczania - wymaganiach szczegółowych w podstawach programowych wychowania przedszkolnego z lat 2012 i 2017

\begin{tabular}{l|l}
\multicolumn{1}{c|}{ NOWA PODSTAWA PROGRAMOWA (2017) } & \multicolumn{1}{|c}{ POPRZEDNIA PODSTAWA PROGRAMOWA (2012) } \\
\hline $\begin{array}{l}\text { III. Społeczny obszar rozwoju dziecka. Dziecko } \\
\text { przygotowane do podjęcia nauki w szkole: }\end{array}$ & $\begin{array}{l}\text { I. Kształtowanie umiejętności społecznych } \\
\text { dzieci: }\end{array}$ \\
\hline $\begin{array}{l}\text { 1) przejawia poczucie własnej wartości jako } \\
\text { osoby, wyraża szacunek wobec innych osób } \\
\text { i przestrzegając tych wartości, nawiązuje rela- } \\
\text { cje rówieśnicze. }\end{array}$ & $\begin{array}{l}\text { 3) w miarę samodzielnie radzi sobie w sytu- } \\
\text { acjach życiowych i próbuje przewidywać skutki } \\
\text { swoich zachowań. }\end{array}$ \\
\hline $\begin{array}{l}\text { 9) komunikuje się z dziećmi i osobami dorosły- } \\
\text { mi, wykorzystując komunikaty werbalne i poza- } \\
\text { werbalne; wyraża swoje oczekiwania społeczne } \\
\text { wobec innego dziecka, grupy. }\end{array}$ \\
\hline $\begin{array}{l}\text { 17) rozpoznaje modele monet i banknotów } \\
\text { o niskich nominałach, porządkuje je, rozumie, } \\
\text { do czego służą pieniądze w gospodarstwie } \\
\text { domowym. }\end{array}$ \\
\hline $\begin{array}{l}\text { 20) wskazuje zawody wykonywane przez } \\
\text { rodziców i osoby z najbliższego otoczenia, } \\
\text { wyjaśnia, czym zajmuje się osoba wykonująca } \\
\text { dany zawód. }\end{array}$
\end{tabular}

Źródło: Opracowanie własne na podstawie Rozporządzenie MEN... $(2012,2017)$.

\section{Ksztaltowanie postaw przedsiębiorczych w edukacji wczesnoszkolnej w świetle podstawy programowej dla klas I-III szkoły podstawowej}

W nowej, ośmioletniej szkole podstawowej w klasach I-III kształcenie w zakresie przedsiębiorczości w ramach edukacji wczesnoszkolnej obejmuje edukację polonistyczną, matematyczną i społeczną (Tab. 2). Również na tym etapie nastąpił wzrost liczby wymagań szczegółowych, zwłaszcza w edukacji społecznej, związanych z przedsiębiorczością. W nowej podstawie uczniowie - oprócz zagadnień związanych z formowaniem się grupy społecznej - powinni również poznać prawa i obowiązki różnych grup (osób), formułować pojęcia takie jak „porozumienie" $\mathrm{i}$ "umowa" oraz sytuacje, w których te pojęcia się stosuje, a także rozwijać umiejętności komunikacji w grupie. Również na tym etapie nastąpiło więc rozszerzenie zapisów wymagań szczegółowych. Pozostały także efekty w zakresie komunikacji werbalnej i niewerbalnej jako element kształcenia polonistycznego oraz obliczenia pieniężne 
w edukacji matematycznej. Ważny jest także efekt odnoszący się do samorozwoju i tworzenia indywidualnych strategii uczenia się, co zalicza się do istotnych postaw i umiejętności osoby przedsiębiorczej (Rachwał 2005, Wellman 2015).

W nowej podstawie programowej z 2017 r. pojawiły się efekty szczegółowe obejmujące edukację techniczną, w której przedsiębiorczości uczniowie uczą się w ramach pracy własnej, realizowanej często w formie projektów, poznając przy tej okazji podstawowe zasady organizacji oraz bezpieczeństwa pracy, co stanowi fundament przygotowania do przyszłej pracy zawodowej.

Należy zaznaczyć, że w poprzedniej podstawie programowej, ze względu na nieco inną formę zapisów, występowały także efekty w zakresie przedsiębiorczości, które były oczekiwane od uczniów kończących III klasę szkoły podstawowej, obejmujące edukację plastyczną i społeczną. W nowej podstawie tego typu zapisy nie występują, gdyż część z nich została przeniesiona na etap wychowania przedszkolnego.

Warto przy tym zaznaczyć za R. Raszką (2015), że - jak wynika z analiz treści programów nauczania i podręczników do klas I-III dostosowanych do poprzedniej podstawy programowej - mimo istnienia formalnych zapisów z trudem można było znaleźć zadania służące budowaniu świadomości pieniądza i jego wartości oraz rozsądnego gospodarowania zasobami pieniężnymi. Pozostaje mieć nadzieję, że w warunkach nowej podstawy programowej takie sytuacje, w których marginalizuje się w praktyce edukacyjnej pewne elementy kształcenia ekonomicznego, nie będą występować.

Tabela 2. Zakładane efekty kształcenia związane z przedsiębiorczością zapisane w treściach nauczania - wymaganiach szczegółowych w podstawach programowych z lat 2012 i 2017 dla klas I-III szkoły podstawowej

\begin{tabular}{l|l}
\multicolumn{1}{c|}{ NOWA PODSTAWA PROGRAMOWA (2017) } & \multicolumn{1}{c}{ POPRZEDNIA PODSTAWA PROGRAMOWA (2012) } \\
\hline I. Edukacja polonistyczna. & I. Edukacja polonistyczna. \\
\hline $\begin{array}{l}\text { 1. 1) słucha z uwagą wypowiedzi nauczyciela, } \\
\text { innych osób z otoczenia, w różnych sytu- }\end{array}$ & 1a) obdarza uwagą dzieci i dorosłych, słucha ich \\
$\begin{array}{l}\text { acjach życiowych, wymagających komunikacji } \\
\text { i wzajemnego zrozumienia; okazuje szacunek } \\
\text { wypowiadającej się osobie. }\end{array}$ & $\begin{array}{l}\text { komunikuje w jasny sposób swoje spostrzeże- } \\
\text { nia, potrzeby, odczucia. }\end{array}$ \\
\hline
\end{tabular}


2. 7) dobiera stosowną formę komunikacji werbalnej i własnego zachowania, wyrażającą empatię i szacunek do rozmówcy.

6. 3) wykorzystuje nabyte umiejętności do rozwiązywania problemów i eksploracji świata, dbając o własny rozwój i tworząc indywidualne strategie uczenia się.

II. Edukacja matematyczna.
6. 3) wykonuje obliczenia pieniężne; zamienia
złote na grosze i odwrotnie, rozróżnia nominały
na monetach i banknotach, wskazuje różnice
w ich sile nabywczej.

7. Edukacja matematyczna.

4) w zakresie obliczeń pieniężnych:

a) zna będące w obiegu monety i banknot o wartości 10 zł; zna wartość nabywczą monet i radzi sobie w sytuacji kupna i sprzedaży, b) zna pojęcie długu i konieczność spłacenia go.

III. Edukacja społeczna.

1. 1) identyfikuje się z grupą społeczną, do której należy: rodzina, klasa w szkole, drużyna sportowa, społeczność lokalna, naród; respektuje normy i reguły postępowania w tych grupach.

1. 2) wyjaśnia, iż wszyscy ludzie posiadają prawa i obowiązki, wymienia własne prawa i obowiązki, przestrzega ich i stosuje je w codziennym życiu.

1. 8) stosuje pojęcia: porozumienie, umowa; uczestniczy w wyborach samorządu uczniowskiego w klasie, w szkole; wymienia przykłady powstałych w efekcie porozumień i umów grup społecznych, np. stowarzyszenia pomocy chorym i niepełnosprawnym dzieciom, organizacje ekologiczne, a także stowarzyszenia dużych grup społecznych, jak miasta i państwa czy Unia Europejska.

1. 10) wykorzystuje pracę zespołową w procesie uczenia się, w tym przyjmując rolę lidera zespołu, i komunikuje się za pomocą nowych technologii.

5. Edukacja społeczna.

2) współpracuje z innymi w zabawie, w nauce szkolnej i w sytuacjach życiowych; przestrzega reguł obowiązujących w społeczności dziecięcej oraz w świecie dorosłych, grzecznie zwraca się do nich w szkole, w domu i na ulicy.

4) ma rozeznanie, że pieniądze otrzymuje się za prace; dostosowuje swe oczekiwania do realiów ekonomicznych rodziny.

7) potrafi wymienić status administracyjny swojej miejscowości (wieś, miasto); wie, czym zajmuje się np. policjant, strażak, lekarz, weterynarz...

\footnotetext{
VI. Edukacja techniczna.

1. 1) planuje i realizuje własne projekty/prace; realizując te projekty/prace, współdziała w grupie.

1. 2) wyjaśnia znaczenie oraz konieczność zachowania ładu, porządku i dobrej organizacji miejsca pracy ze względów bezpieczeństwa.
} 


\begin{tabular}{l|l}
\hline $\begin{array}{l}\text { 1. 3) ocenia projekty/prace, wykorzystując } \\
\text { poznane i zaakceptowane wartości: systema- } \\
\text { tyczność działania, pracowitość, konsekwencja, } \\
\begin{array}{l}\text { gospodarność, oszczędność, umiar w odnie- } \\
\text { sieniu do korzystania z czasu, materiałów, } \\
\text { narzędzi i urządzeń. }\end{array}\end{array}$ & \\
\hline & $\begin{array}{l}\text { 4. Edukacja plastyczna. Uczeń kończący } \\
\text { klasę Ill: }\end{array}$ \\
\hline & $\begin{array}{l}\text { 2b) realizuje proste projekty w zakresie form } \\
\text { użytkowych, w tym służące kształtowaniu wła- } \\
\text { snego wizerunku i otoczenia oraz upowszech- } \\
\text { nianiu kultury w środowisku szkolnym (stosując } \\
\text { określone narzędzia i wytwory przekazów } \\
\text { medialnych). }\end{array}$ \\
\hline & $\begin{array}{l}\text { 5. Edukacja społeczna. Uczeń kończący } \\
\text { klasę Ill: }\end{array}$ \\
\hline $\begin{array}{l}\text { 2) identyfikuje się ze swoją rodziną i z jej } \\
\text { tradycjami; podejmuje obowiązki domowe i rze- } \\
\text { telnie je wypełnia; rozumie, co to jest sytuacja } \\
\text { ekonomiczna rodziny, i wie, że trzeba do niej } \\
\text { dostosować swe oczekiwania. }\end{array}$ \\
\hline $\begin{array}{l}\text { 3) wie, jak należy zachowywá́ się w stosunku } \\
\text { do dorosłych i rówieśników (formy grzecz- } \\
\text { nościowe); rozumie potrzebę utrzymywania } \\
\text { dobrych relacji z sąsiadami w miejscu zamiesz- } \\
\text { kania; jest chętny do pomocy, respektuje prawo } \\
\text { innych do pracy i wypoczynku. }\end{array}$ \\
$\begin{array}{l}\text { 8) wie, jak ważna jest praca w życiu człowieka; } \\
\text { wie, jaki zawód wykonują jego najbliżsi i znajo- } \\
\text { mi; wie, czym zajmuje się np. kolejarz, aptekarz, } \\
\text { policjant, weterynarz. }\end{array}$ \\
\hline
\end{tabular}

Źródło: Opracowanie własne na podstawie Rozporządzenia MEN... $(2012,2017)$.

\section{Ksztaltowanie postaw przedsiębiorczych w klasach IV-VIII szkoły podstawowej w świetle podstawy programowej}

W wyższych klasach ośmioletniej szkoły podstawowej (IV-VIII) zagadnienia związane z przedsiębiorczością znajdują się w podstawach programowych poszczególnych przedmiotów szkolnych (Tab. 3).

W podstawie programowej języka polskiego - poza pozostawieniem wymagania obejmującego identyfikację wypowiedzi (w tym reklamowej) - zapisano także trzy inne efekty odwołujące się do kształcenia w zakresie komunikacji. W najwyższych klasach uczniowie zapoznają się również z tworzeniem wypowiedzi w formie CV czy listu moty- 
wacyjnego, które w szkole średniej są kontynuowane w ramach lekcji przedsiębiorczości.

Kolejnym przedmiotem szkolnym, w którego podstawie znajdujemy treści nawiązujące do przedsiębiorczości, jest wiedza o społeczeństwie. W poprzedniej podstawie programowej w młodszych klasach szkoły podstawowej przedmiot ten był nazwany "historia i społeczeństwo", a dopiero w kolejnym, gimnazjalnym etapie kształcenia występował jako wiedza o społeczeństwie. Zmiana ta spowodowała, że w nowej podstawie programowej pojawia się wiele zapisów efektów szczegółowych odnoszących się do kształtowania przedsiębiorczości: związanych z komunikowaniem się, z konfliktami w grupie, z poznawaniem funkcjonowania gospodarstwa domowego, z planowaniem własnego rozwoju oraz z funkcjonowaniem rynku pracy i samorządu gminnego. W poprzedniej podstawie programowej na etapie szkoły podstawowej pojawił się jedynie jeden zapis dotyczący przedsiębiorczości. Wynikało to z faktu, że na etapie gimnazjum wiedza o społeczeństwie w znacznej części zawierała zagadnienia dotyczące przedsiębiorczości.

W podstawie programowej do szkoły podstawowej w zakresie geografii również znajdujemy kilka zagadnień dotyczących przedsiębiorczości, szczególnie społeczno-gospodarczych aspektów rozwoju obszaru Polski i innych krajów oraz współpracy w zespole. W poprzedniej podstawie, ze względu na to, że dominowało kształcenie w zakresie przyrody, które nie nawiązywało do przedsiębiorczości, nie znajdujemy zapisów dla kształcenia geograficznego, które obejmowałyby przedsiębiorczość. Przywrócenie w szkole podstawowej geografii od V klasy oznacza więc włączenie do kształcenia już na tym etapie elementów geografii społeczno-ekonomicznej, której wiele treści wspiera kształtowanie postaw przedsiębiorczych i osiąganie efektów związanych z wiedzą ekonomiczną o otaczającym świecie. W warunkach poprzedniej podstawy programowej geografia wspierała edukację w zakresie przedsiębiorczości głównie na etapie szkoły ponadgimnazjalnej i częściowo gimnazjum (Borowiec, Rachwał 2011)1.

Obecnie ważnym przedmiotem w szkole podstawowej podnoszącym zagadnienia z przedsiębiorczości jest także wychowanie do życia w rodzinie, w którego podstawie programowej znalazły się zapisy 
dotyczące rozszerzania zarówno umiejętności i wiedzy związanych z kształtowaniem postaw, jak i komunikacji, w tym w sytuacjach konfliktowych.

W obecnej podstawie programowej także na etyce pojawiają się obszary nawiązujące do przedsiębiorczości - poznanie własnych wad i zalet oraz praw i obowiązków, które w poprzedniej podstawie programowej nie występowały.

Tabela 3. Zakładane efekty kształcenia związane z przedsiębiorczością zapisane w treściach nauczania - wymaganiach szczegółowych w podstawach programowych z lat 2012 i 2017 dla klas IV-VIII szkoły podstawowej

\begin{tabular}{|c|c|}
\hline NOWA PODSTAWA PROGRAMOWA (2017) & POPRZEDNIA PODSTAWA PROGRAMOWA (2012) \\
\hline \multicolumn{2}{|c|}{ JĘZYK POLSKI } \\
\hline Kształcenie literackie i kulturowe. & $\begin{array}{l}\text { I. Odbiór wypowiedzi i wykorzystanie zawartych } \\
\text { w nich informacji. }\end{array}$ \\
\hline $\begin{array}{l}\text { 2. 1) identyfikuje wypowiedź jako tekst infor- } \\
\text { macyjny, publicystyczny lub reklamowy. }\end{array}$ & $\begin{array}{l}\text { 4) identyfikuje wypowiedź jako tekst informa- } \\
\text { cyjny, literacki, reklamowy. }\end{array}$ \\
\hline \multicolumn{2}{|l|}{$\begin{array}{l}\text { 3. 1) identyfikuje tekst jako komunikat; roz- } \\
\text { różnia typy komunikatu: informacyjny, literacki, } \\
\text { reklamowy, ikoniczny. }\end{array}$} \\
\hline \multicolumn{2}{|l|}{$\begin{array}{l}\text { 3. 3) określa sytuację komunikacyjną i rozumie } \\
\text { jej wpływ na kształt wypowiedzi. }\end{array}$} \\
\hline \multicolumn{2}{|l|}{$\begin{array}{l}\text { 3. 4) rozpoznaje znaczenie niewerbalnych środ- } \\
\text { ków komunikacji (np. gest, mimika, postawa } \\
\text { ciała). }\end{array}$} \\
\hline & 1. Mówienie i pisanie. \\
\hline & $\begin{array}{l}\text { 5) tworzy wypowiedzi pisemne } \\
\text { w następujących formach gatunkowych: } \\
\text { opowiadanie z dialogiem (twórcze } \\
\text { i odtwórcze), pamiętnik i dziennik (pisane } \\
\text { z perspektywy bohatera literackiego } \\
\text { lub własnej), list oficjalny, proste } \\
\text { sprawozdanie (np. z wycieczki, z wydarzeń } \\
\text { sportowych), opis postaci, przedmiotu, } \\
\text { krajobrazu, ogłoszenie, zaproszenie, prosta } \\
\text { notatka. }\end{array}$ \\
\hline \multicolumn{2}{|l|}{ III. Tworzenie wypowiedzi. } \\
\hline $\begin{array}{l}\text { 1) tworzy spójne wypowiedzi w następujących } \\
\text { formach gatunkowych: recenzja, rozprawka, } \\
\text { podanie, życiorys, CV, list motywacyjny, prze- } \\
\text { mówienie, wywiad. }\end{array}$ & \\
\hline
\end{tabular}




\begin{tabular}{|c|c|}
\hline WIEDZA O SPOŁECZEŃSTWIE & HISTORIA I SPOŁECZEŃSTWO \\
\hline \multicolumn{2}{|l|}{$\begin{array}{l}\text { I. 2) przedstawia zasady komunikowania się; } \\
\text { wyjaśnia zasady skutecznej autoprezentacji - } \\
\text { kształtowania swojego wizerunku. }\end{array}$} \\
\hline $\begin{array}{l}\text { I. 3) wymienia cechy grup społecznych; charak- } \\
\text { teryzuje grupę koleżeńską i grupę nastawioną } \\
\text { na realizację określonego zadania; uzasadnia, że } \\
\text { efektywna współpraca przynosi różne korzyści; } \\
\text { przedstawia różne formy współpracy w grupie. }\end{array}$ & $\begin{array}{l}\text { 3) wyjaśnia znaczenie rodziny w życiu oraz } \\
\text { wskazuje przykłady praw i obowiązków przy- } \\
\text { sługujących poszczególnym członkom rodziny. }\end{array}$ \\
\hline \multicolumn{2}{|l|}{$\begin{array}{l}\text { I. 6) uzasadnia, że konflikt w grupie może wy- } \\
\text { nikać z różnych przyczyn (sprzeczne interesy, } \\
\text { inne cele); przedstawia sposoby rozwiązywania } \\
\text { konfliktów oraz analizuje ich zalety i wady. }\end{array}$} \\
\hline \multicolumn{2}{|l|}{$\begin{array}{l}\text { II. 3) wyjaśnia, jak funkcjonuje gospodarstwo } \\
\text { domowe; wymienia główne źródła jego docho- } \\
\text { dów (z działalności zarobkowej: pracy, działal- } \\
\text { ności gospodarczej, umów cywilnoprawnych } \\
\text { oraz ze świadczeń społecznych - w powiązaniu } \\
\text { z rodzajami ubezpieczeń społecznych). }\end{array}$} \\
\hline \multicolumn{2}{|l|}{$\begin{array}{l}\text { II. 4) wymienia kategorie wydatków gospodar- } \\
\text { stwa domowego; planuje jego budżet. }\end{array}$} \\
\hline \multicolumn{2}{|l|}{$\begin{array}{l}\text { III. 4) charakteryzuje oczekiwane kompetencje } \\
\text { wybranych kategorii społeczno-zawodowych } \\
\text { i ich miejsce na rynku pracy; }\end{array}$} \\
\hline \multicolumn{2}{|l|}{$\begin{array}{l}\text { III. 5) planuje dalszą edukację, uwzględniając } \\
\text { własne zainteresowania, zdolności i umiejęt- } \\
\text { ności oraz rady innych osób i sytuację na rynku } \\
\text { pracy. }\end{array}$} \\
\hline \multicolumn{2}{|l|}{$\begin{array}{l}\text { VI. 1) wymienia zadania samorządu gminnego; } \\
\text { przedstawia główne źródła przychodów i kie- } \\
\text { runki wydatków w budżecie gminy. }\end{array}$} \\
\hline \multicolumn{2}{|l|}{$\begin{array}{l}\text { IX. 1) podaje cnoty obywatelskie (odpowie- } \\
\text { dzialność, troska o dobro wspólne, aktywność, } \\
\text { przedsiębiorczość, solidarność, roztropność, } \\
\text { tolerancja, odwaga cywilna); wykazuje, odwołu- } \\
\text { jąc się do działań wybitnych Polaków, znaczenie } \\
\text { ich urzeczywistnienia dla pożytku publicznego. }\end{array}$} \\
\hline \multicolumn{2}{|l|}{$\begin{array}{l}\text { X. 3) przedstawia funkcje reklamy i krytycznie } \\
\text { analizuje wybrany przekaz reklamowy. }\end{array}$} \\
\hline & $\begin{array}{l}\text { 1. 5) charakteryzuje społeczność szkolną, } \\
\text { z uwzględnieniem swoich praw i obowiązków. }\end{array}$ \\
\hline & $\begin{array}{l}\text { 2. 1) opisuje swoją „małą ojczyznę”, uwzględ- } \\
\text { niając tradycję historyczno-kulturową i proble- } \\
\text { my społeczno-gospodarcze. }\end{array}$ \\
\hline & $\begin{array}{l}\text { 2. 3) wskazuje na planie miejscowości, siedzibę } \\
\text { władz lokalnych i na przykładach omawia za- } \\
\text { kres działań oraz sposoby powoływania władz. }\end{array}$ \\
\hline
\end{tabular}


1. 3) podaje przykłady praw i obowiązków obywateli Rzeczypospolitej Polskiej.

5. 1) wyjaśnia znaczenie pracy w życiu człowieka i dostrzega jej społeczny podział.

25. 4) opisuje warunki pracy w XIX-wiecznej fabryce.

\section{GEOGRAFIA}

\begin{tabular}{|c|c|}
\hline $\begin{array}{l}\text { X. 7) wykazuje znaczenie poszczególnych sek- } \\
\text { torów gospodarki w rozwoju kraju oraz określa } \\
\text { różnice w strukturze zatrudnienia ludności } \\
\text { w Polsce i w wybranych państwach europej- } \\
\text { skich. }\end{array}$ & $\begin{array}{l}\text { Geografia nie występowała w szkole podsta- } \\
\text { wowej. }\end{array}$ \\
\hline $\begin{array}{l}\text { X. 8) porównuje wielkość bezrobocia w Polsce } \\
\text { i innych krajach europejskich oraz określa jego } \\
\text { przyczyny i skutki w Polsce. }\end{array}$ & \\
\hline $\begin{array}{l}\text { X. 13) podaje przykłady różnych rodzajów usług } \\
\text { w Polsce oraz ocenia znaczenie transportu } \\
\text { i łączności dla jakości życia mieszkańców i roz- } \\
\text { woju gospodarczego naszego kraju. }\end{array}$ & \\
\hline $\begin{array}{l}\text { X. 16) podaje przykłady osiągnięć Polaków } \\
\text { w różnych dziedzinach życia społeczno- } \\
\text {-gospodarczego oraz sukcesów polskich przed- } \\
\text { siębiorstw na arenie międzynarodowej. }\end{array}$ & \\
\hline $\begin{array}{l}\text { X. 17) jest świadomy tego, że może mieć } \\
\text { w przyszłości wpływ na rozwój społeczno- } \\
\text {-gospodarczy i kulturowy Polski. }\end{array}$ & \\
\hline $\begin{array}{l}\text { XI. 6) identyfikuje związki między przebiegiem } \\
\text { autostrad i dróg ekspresowych a lokalizacją } \\
\text { przedsiębiorstw przemysłowych, centrów } \\
\text { logistycznych i handlowych w obszarze metro- } \\
\text { politalnym Wrocławia oraz między transportem } \\
\text { morskim a lokalizacją inwestycji przemysło- } \\
\text { wych i usługowych na przykładzie Trójmiasta. }\end{array}$ & \\
\hline $\begin{array}{l}\text { XIII. 3) przedstawia w dowolnej formie (np. pre- } \\
\text { zentacji multimedialnej, plakatu, filmu, wystawy } \\
\text { fotograficznej) atrakcyjność "małej ojczyzny” } \\
\text { jako miejsca zamieszkania i działalności gospo- } \\
\text { darczej na podstawie informacji wyszukanych } \\
\text { w różnych źródłach. }\end{array}$ & \\
\hline
\end{tabular}

\begin{tabular}{l|l}
\hline \multicolumn{2}{c}{ MATEMATYKA } \\
\hline $\begin{array}{l}\text { Klasy VII-VIII: } \\
\begin{array}{l}\text { V. 5) stosuje obliczenia procentowe do rozwią- } \\
\text { zywania problemów w kontekście praktycznym, } \\
\text { również w przypadkach wielokrotnych podwy- } \\
\text { żek lub obniżek danej wielkości. }\end{array}\end{array}$ \\
\hline \multicolumn{1}{c}{ INFORMATYKA } & \multicolumn{1}{c}{ ZAJĘCIA KoMPUTERowE } \\
\hline $\begin{array}{l}\text { Klasy IV-VI: } \\
\begin{array}{l}\text { IV. 2) identyfikuje i docenia korzyści płynące } \\
\text { ze współpracy nad wspólnym rozwiązywaniem } \\
\text { problemów. }\end{array}\end{array}$ & $\begin{array}{l}\text { 5.2) uczestniczy w pracy zespołowej, porozu- } \\
\text { miewa się z innymi osobami podczas realizacji } \\
\text { wspólnego projektu, podejmuje decyzje w za- } \\
\text { kresie swoich zadań i uprawnień. }\end{array}$ \\
\hline
\end{tabular}


IV. 4) określa zawody i wymienia przykłady z życia codziennego, w których są wykorzystywane kompetencje informatyczne.

4. 2) opracowuje i redaguje teksty (listy, ogłoszenia, zaproszenia, ulotki, wypracowania), stosując podstawowe możliwości edytora tekstu w zakresie formatowania akapitu i strony, łączy grafikę z tekstem.

\section{Klasa VII-VIII:}

IV. 4) określa zakres kompetencji informatycznych, niezbędnych do wykonywania różnych zawodów, rozważa i dyskutuje wybór dalszego i pogłębionego kształcenia, również w zakresie informatyki.

\section{TECHNIKA}

I. 5) współpracuje i podejmuje różne role w pracy w zespole.

\section{WYCHOWANIE DO ŻYCIA W RODZINIE}

VI. 3) radzi sobie w sytuacji konfliktu, presji grupy, stresu.

VI. 4) zna i stosuje zasady savoir-vivre'u w różnych sytuacjach społecznych.

3. Więź rodzinna, związki uczuciowe i inne relacje w rodzinie; konflikty i ich rozwiązywanie.

VI. 5) rozumie zasady komunikacji werbalnej i niewerbalnej $\mathrm{i}$ jej znaczenie $w$ relacjach interpersonalnych; przyjmuje odpowiedzialność za manifestowane reakcje, wypowiadane i pisane słowa.

VI. 6) kształtuje i wyraża postawy asertywne, gdy nie może lub nie powinien czegoś wykonać, stara się odmawiać tak, by nie ranić drugiego.

VI. 7) bierze udział w życiu społecznym przez: wolontariat, stowarzyszenia, grupy nieformalne i aktywność indywidualną; ujawnia wrażliwość na osoby potrzebujące pomocy i zna konkretne sposoby jej udzielania.

\section{ETYKA}

III. 3) zna i rozwija swoje zalety, rozpoznaje i eliminuje swoje wady.

III. 4) zna swoje podstawowe prawa i obowiązki (ucznia, dziecka) oraz wypełnia własne obowiązki.

4. Przyjmowanie odpowiedzialności za siebie.

8. Praca i jej wartość dla człowieka.

\section{JĘZYK MNIEJSZOŚCI NARODOWEJ LUB ETNICZNEJ}

3. 5) identyfikuje wypowiedź jako tekst reklamowy, informacyjny.
2. 5) identyfikuje wypowiedź jako tekst literacki, reklamowy, informacyjny.

Źródło: Opracowanie własne na podstawie Rozporządzenia MEN... $(2012,2017)$. 
Porównanie podstaw programowych w starszych klasach szkoły podstawowej nie jest sprawą prostą, co wynika ze zmiany całego systemu szkolnego w wyniku reformy. W konsekwencji tych zmian zlikwidowano gimnazja, wydłużono edukację w szkole podstawowej z sześciu do ośmiu klas, a w liceum i technikum - o rok kształcenia. Należy więc zauważyć, że zagadnienia związane z przedsiębiorczością w podstawie programowej na trzecim etapie edukacyjnym (gimnazjum) w poprzedniej podstawie programowej były zapisane w kilku przedmiotach, głównie w wiedzy o społeczeństwie i języku polskim. Część z nich została uwzględniona w zapisach podstawy programowej dla nowej, ośmioklasowej szkoły podstawowej lub przeniesiona do szkoły średniej, które zyskały dodatkowy rok na realizację tych treści. W poprzedniej podstawie programowej dla przedmiotu język polski były zapisane efekty związane z odbieraniem komunikatów i tworzeniem spójnych wypowiedzi ustnych i pisemnych (w tym w formie życiorysu, CV i listu motywacyjnego).

Głównym przedmiotem rozwijającym kompetencje przedsiębiorcze i dającym podstawy wiedzy ekonomicznej w ramach byłego gimnazjum była wiedza o społeczeństwie. Zapisy w poprzedniej podstawie programowej z tego zakresu były przedmiotem wcześniejszego zainteresowania badaczy i poddano je szczegółowej analizie (Kurek, Rachwał 2010, Kurek, Rachwał, Szubert 2012, Berger i in. 2012, Rachwał, Kurek, Boguś 2016). Należy jednak w tym miejscu zaznaczyć, że zapisano w niej wiele treści odnoszących się do przedsiębiorczości. Jak wskazały jednak badania w środowisku szkolnym (Kurek, Rachwał, Szubert 2012), bardzo często były one w praktyce edukacyjnej marginalizowane przez nauczycieli wiedzy o społeczeństwie. Wynikało to z wielu przyczyn, wśród których najważniejsze to brak przygotowania nauczycieli tego przedmiotu do realizacji treści ekonomiczno-biznesowych czy finansowych oraz brak czasu na realizację zbyt rozbudowanej podstawy programowej. Niemniej w podstawie programowej wiedzy o społeczeństwie formalnie występowało wiele zapisów wymagań szczegółowych związanych z przedsiębiorczością,w następujących działach (grupach treści kształcenia):

$\rightarrow$ Podstawowe umiejętności życia w grupie (w tym głównie efekty związane z komunikacją interpersonalną oraz podejmowaniem decyzji).

$\rightarrow$ Praca i przedsiębiorczość (efekty związane głównie z cechami osoby przedsiębiorczej oraz zasadami organizacji pracy). 
$\rightarrow$ Gospodarka rynkowa (poznanie podmiotów gospodarki, zasad racjonalnego gospodarowania, cech gospodarki rynkowej i działania popytu i podaży).

$\rightarrow$ Gospodarstwo domowe (jak funkcjonuje, jak układa się jego budżet, prawa konsumenta).

$\rightarrow$ Pieniądz i banki ( $w$ tym funkcje i formy pieniądza, wybrane instytucje finansowe, oferta usług bankowych).

$\rightarrow$ Gospodarka w skali państwa (w tym wskaźniki gospodarcze, budżet państwa, podatki).

$\rightarrow$ Przedsiębiorstwo i działalność gospodarcza (w tym efekty dotyczące wyjaśnienia, na czym polega prowadzenie indywidualnej działalności gospodarczej i jak "działa przedsiębiorstwo", jakie są elementy działań marketingowych oraz główne prawa i obowiązki pracownika, a także czemu służą ubezpieczenia społeczne i zdrowotne).

$\rightarrow$ Wybór szkoły i zawodu (w tym planowanie własnej edukacji, wyszukiwanie informacji o możliwościach zatrudnienia, sporządzanie życiorysu i listu motywacyjnego, przyczyny bezrobocia i ocenianie jego skutków).

$\rightarrow$ Etyka w życiu gospodarczym (w tym społeczna odpowiedzialność biznesu, szara strefa i korupcja w życiu społeczno-gospodarczym).

Może się wydawać, że treści te zniknęły z wiedzy o społeczeństwie wraz z likwidacją gimnazjum. Tak się jednak nie stało. Część z nich, związanych głównie z przedsiębiorczością jako postawą człowieka, komunikacją interpersonalną i budżetami gospodarstw domowych, została włączona do wiedzy o społeczeństwie w VIII klasie szkoły podstawowej, a pozostałe przeniesiono do szkoły średniej albo w ramach tego przedmiotu (np. ubezpieczenia społeczne i budżet państwa bądź jednostek samorządu terytorialnego), albo $w$ ramach podstaw przedsiębiorczości (o czym szerzej będzie mowa w innym opracowaniu ujętym w niniejszym tomie).

Warto zwrócić także uwagę, że zgodnie z wcześniejszymi postulatami środowisk naukowych i oświatowych związanych z edukacją w zakresie przedsiębiorczości (zob. Rachwał 2017) wyeliminowano występujące wcześniej zbędne powtórzenia zapisów efektów w gimnazjum i szkole średniej, porządkując nieco te treści oraz urealniając 
możliwości realizacji efektów kształcenia w ramach wiedzy o społeczeństwie i podstaw przedsiębiorczości. Usunięto także nieprecyzyjne zapisy, co do których nauczyciel miał wątpliwości, na przykład „[uczeń] wyjaśnia, jak działa przedsiębiorstwo" można interpretować zarówno bardzo wąsko, jak i bardzo szeroko. Był to również jeden z postulatów nauczycieli przedsiębiorczości (Rachwał 2017).

W warunkach poprzedniej podstawy programowej edukację w zakresie przedsiębiorczości wspierała geografia. Zagadnienie to było przedmiotem wcześniejszej szczegółowej analizy Moniki Borowiec i Tomasza Rachwała (2011). Rola geografii w tym zakresie, jak się wydaje, wzrosła - ze względu na włączenie w większym zakresie treści z dziedziny geografii społeczno-ekonomicznej. Warto także zwrócić uwagę, że do podstawy programowej historii w większym stopniu niż dotychczas wprowadzono zapisy odnoszące się do historii gospodarczej, co sprzyja późniejszemu kształtowaniu umiejętności rozumienia procesów zachodzących współcześnie w gospodarce w ramach lekcji geografii i podstaw przedsiębiorczości w szkole średniej.

\section{Zakończenie}

Analiza zapisów nowej podstawy programowej wychowania przedszkolnego i kształcenia ogólnego w ośmioletniej szkole podstawowej wskazuje, że utrzymano i nieco rozszerzono dotychczasowe zapisy odnoszące się do wiedzy ekonomiczno-finansowej oraz kształtowania umiejętności i postaw związanych z przedsiębiorczością. Zgodnie z postulatami wielu nauczycieli, specjalistów, badaczy i propagatorów edukacji ekonomicznej niektóre zapisy pojawiają się na wcześniejszych etapach kształcenia. Przykładem są elementy edukacji finansowej związanej z rolą pieniądza (głównie w życiu rodziny) i wykonywaniem pracy w różnych zawodach na poziomie edukacji wczesnoszkolnej.

Przyjęto ponadto założenie, że umiejętności w zakresie komunikacji interpersonalnej powinny być już w znacznym stopniu ukształtowane na etapie szkoły podstawowej, dlatego nie są one w zakresie elementarnym powtarzane na etapie szkoły średniej. Choć na etapie szkoły podstawowej nie jest realizowany przedmiot podstawy przedsiębiorczości, to jednak zapisy dotyczące przedsiębiorczości występują w wielu przedmiotach szkolnych. Tym samym można uznać, że zapisy nowej podstawy programowej sprzyjają postulatom wielu autorów (Oeszlaeger-Kosturek 2017, Rachwał 2017, Raszka 2017, Zioło 2012), 
przynajmniej częściowo wypełniając luki w przestrzeni edukacyjnej w tym zakresie, na który zwrócił uwagę Tomasz Kopczyński (2017).

Należy jednak zaznaczyć, że nawet najlepsze zapisy podstawy programowej nie gwarantują, że efekty kształcenia w zakresie przedsiębiorczości będą osiągane w zadowalającym stopniu. Niezbędni w tym procesie są kompetentni nauczyciele różnych przedmiotów, rozumiejący istotę kształtowania postaw przedsiębiorczych dzieci i młodzieży. 


\section{Bibliografia}

$\rightarrow$ Berger, S., Canning, R., Dolan, M., Kurek, S., Pilz, M., Rachwał, T. (2012), Curriculum-making in pre-vocational education in the lower secondary school: A regional comparative analysis within Europe, „Journal of Curriculum Studies", nr 44 (5), s. 679-701.

$\rightarrow$ Borowiec, M., Rachwał, T. (2011), Kształtowanie postaw przedsiębiorczych na lekcjach geografii wyzwaniem edukacyjnym w procesach globalizacji, „Przedsiębiorczość - Edukacja", nr 7, s. 321-332.

$\rightarrow$ Kopczyński, T. (2017), Brakujq̨ce elementy kształtowania przedsiębiorczości w przestrzeni edukacyjnej [w:] A. Murzyn, U. Szuścik (red.), Przedsiębiorczość jako wartość edukacji, Katowice: Wydawnictwo Uniwersytetu Śląskiego, s. 83-93.

$\rightarrow$ Kurek, S., Rachwał, T. (2010), Założenia i wstępne wyniki europejskiego projektu badawczego "FIFOBI" w zakresie kształtowania kompetencji uczniów gimnazjum do prowadzenia działalności gospodarczej, „Przedsiębiorczość-Edukacja”, nr 6, s. 472-485.

$\rightarrow$ Kurek, S., Rachwał, T., Szubert, M. (2012), Business Competencies in Polish School Curricula: Opinions of Teachers and Social Partners [w:] M. Pilz, S. Berger, R. Canning (red.), Fit for Business. Pre-Vocational Education in European Schools, Wiesbaden: VS Verlag für Sozialwissenschaften, Springer, s. 61-88.

$\rightarrow$ Oeszlaeger-Kosturek, B. (2017), Przedsiębiorczość - istota i sposoby kształtowania w procesie edukacji wczesnoszkolnej [w:] A. Murzyn, U. Szuścik (red.), Przedsiębiorczość jako wartość edukacji, Katowice: Wydawnictwo Uniwersytetu Śląskiego, s. 154-166.

$\rightarrow$ Rachwał, T. (2005), Kształtowanie postaw uczniów na lekcjach podstaw przedsiębiorczości, „Przedsiębiorczość - Edukacja”, nr 1, s. 137-144.

$\rightarrow$ Rachwał, T. (2006), Kształtowanie postaw przedsiębiorczych w edukacji szkolnej [w:] B. Muchacka (red.), Szkoła w nauce i praktyce edukacyjnej, t. 2, Kraków: Oficyna Wydawnicza „Impuls", Akademia Pedagogiczna w Krakowie, s. 427-434. 
$\rightarrow$ Rachwał, T. (2017), Entrepreneurship in School in the Conditions of the Education System Reform in Poland - a Voice in the Discussion on the Directions of Change, „Przedsiębiorczość - Edukacja”, 1nr 3, s. 330-339.

$\rightarrow$ Rachwał, T., Kurek, S., Boguś, M. (2016), Entrepreneurship Education at Secondary Level in Transition Economies: A Case of Poland, „Entrepreneurial Business and Economics Review", nr 4 (1), s. 61-81.

$\rightarrow$ Raszka, R. (2017), Edukacja finansowa dzieci [w:] A. Murzyn, U. Szuścik (red.), Przedsiębiorczość jako wartość edukacji, Katowice: Wydawnictwo Uniwersytetu Śląskiego, s. 140-153.

$\rightarrow$ Rozporządzenie MEN... (2012), Rozporządzenie Ministra Edukacji Narodowej z dnia 27 sierpnia 2012 r. w sprawie podstawy programowej wychowania przedszkolnego oraz kształcenia ogólnego w poszczególnych typach szkół (Dz.U. 2012, poz. 977).

$\rightarrow$ Rozporządzenie MEN... (2017), Rozporządzenie Ministra Edukacji Narodowej z dnia 14 lutego 2017 r. w sprawie podstawy programowej wychowania przedszkolnego oraz podstawy programowej kształcenia ogólnego dla szkoły podstawowej, w tym dla uczniów z niepełnosprawnością intelektualną w stopniu umiarkowanym lub znacznym, kształcenia ogólnego dla branżowej szkoły I stopnia, kształcenia ogólnego dla szkoły specjalnej przysposabiającej do pracy oraz kształcenia ogólnego dla szkoły policealnej (Dz.U. 2017, poz. 356).

$\rightarrow$ Tracz, M. (2006), Rola i znaczenie „podstaw przedsiębiorczości” w kształceniu ogólnym, „Przedsiębiorczość - Edukacja”, nr 2, s. 222-225.

$\rightarrow$ Tracz, M. (2015), Przedmiot podstawy przedsiębiorczości w opinii uczniów i nauczycieli - studium porównawcze, „Przedsiębiorczość - Edukacja”, nr 11, s. 391-400.

$\rightarrow$ Wach, K. (2013), Edukacja na rzecz przedsiębiorczości wobec współczesnych wyzwań cywilizacyjno-gospodarczych, „Przedsiębiorczość - Edukacja”, nr 9, s. 246-257.

$\rightarrow$ Wach, K. (2014), Edukacja dla przedsiębiorczości: pomiędzy przedsiębiorczą pedagogikq a edukacjq ekonomicznq i biznesowq, "Horyzonty Wychowania”, $\mathrm{nr} 13$ (28), s. 11-31.

$\rightarrow$ Wollman, L. (2015), Rozwijanie potencjału uczenia się w ujęciu Guya Claxtona [w:] J. Uszyńska-Jarmoc, M. Bilewicz (red.), Kompetencje kluczowe dzieci i młodzieży. Teoria i badania, Warszawa: Wydawnictwo Akademickie Żak, s. 97-108.

$\rightarrow$ Wollman, L. (2017), Przedsiębiorczość w procesie uczenia się w koncepcji Guya Claxtona [w:] A. Murzyn, U. Szuścik (red.), Przedsiębiorczość jako wartość edukacji, Katowice: Wydawnictwo Uniwersytetu Śląskiego, s. 128-139.

$\rightarrow$ Zioło, Z. (2012), Miejsce przedsiębiorczości w edukacji, „Przedsiębiorczość- Edukacja", nr 8, s. 10-23. 